\title{
Evaluating the Scale of the Second Wave of Taiwan High School Graduates Brain Drain Initiative
}

\author{
Ying-Lung Liu \\ Doctoral Student \\ National Taiwan University \\ Graduate Institute of National Development \\ No. 1, Sec. 4, Roosevelt Road, Taipei, Taiwan 10617 \\ Advisor
Jih-Shine Chou
Professer
National Taiwan University
Graduate Institute of National Development
No. 1, Sec. 4, Roosevelt Road, Taipei, Taiwan 10617
}

\begin{abstract}
Taiwan first wave brain drain of college graduates occurred during from 1962 to 1967, their had 51,218 individuals went abroad to United State from Taiwan. Under long-term economic stagnation and China 31 incentive dual effects, the second wave brain drain of high school graduates in Taiwan initiative after 2018 spring. This study aims to evaluate the scale of Taiwan high school graduates' perspectives of brain drain. With the push and pull theory to validate graduates' aspiration of brain drain, and using exploratory factors analysis to construct factors structure, this scale could effectively provide self-assessment for those high school graduates who are interested in studying abroad. We also create a Brain Drain Ratio(BDR) to validate the extent of graduates' brain drain. By open-ended survey data showed that China has become the second priority of brain drain destination for Taiwanese high school graduates from 2018.
\end{abstract}

Key words: brain drain, exploratory factors analysis, the second wave, push and pull factors, china 31 Incentives Validating scale

\section{Introduction}

\section{Taiwan second wave brain drain initiative}

Due to the stagnation of economic development in Taiwan, the external migration of manufacturers getting more seriously. The urban housing prices too high to afford that young people are pessimistic about the future prospects, and also the average starting monthly salaries for university graduates reached a peak of NT\$28,116 (US\$963) last June in $2017^{1}$. , and youths net wages in Taiwan have struggled to keep pace over the past two decades ${ }^{2}$. . So flipping dilemma for achieve better future become most of Taiwan youths' visions of reality . Meanwhile China released favorable policies (China's 31 Incentives) that especially advantageous for Taiwan youths on the February 2018, significantly reduced the application standards of China elite universities for Taiwan high school graduates. Both low tuition and same language advantages were also actually encouraged lots of Taiwan high school graduates. A poll survey from Taiwan public opion foundation showed that there're $40 \%$ among youths between the ages of 20 and 24 , and 38\% respondents those with higher education both thought China 31 Incentives good for their future development ${ }^{3}$.

Studying abroad is no longer a top-notch patent for a few elites in Taiwan since China 31 incentives revealed. It really encouraged more middle-class graduates to pursuit going abroad for better future that leading the second wave of brain drain initiative in Taiwan.

\footnotetext{
${ }^{1}$ Timothy Ferry (2018) Taiwan Competes for Talent and Manpower Taiwan Bussness Topics

${ }^{2}$ Ralph Jennings(2018) Why Taiwan's Wages Are Low For A Developed Asian Economy Forbes

${ }^{3}$ Elizabeth Hsu(2018)CNA Six in 10 Think China's Incentives Could Lure Taiwanese: Poll Taiwan Competitiveness Forum
} 


\section{The Theory Framework}

Classic approach to the migration is push-pull theory. This theory proposed by Ernest Ravenstein who analyzed internal migration in England during 1870s $\mathrm{s}^{4}$. Ravenstein believed that pull factors play a more important role than push factors causing migration. He also acknowledged that the most important factor motivating people to migrate is a desire to improve their lives rather than away from disappointed original. Then in terms of studying the causes of population mobility, the most important macro-collection theory in demography is the push-pull theory. The first to put forward this theory is D.J.Bagne, He believed that both the outflow and inflow land have both tension and thrust, and at the same time supplement the third factor: the intermediate obstacle factor. The intermediate obstacles mainly include the distance, the material barriers, the difference in language and culture, and the value judgment of the immigrants on these factors. Population mobility is the result of a combination of these three factors.

Everett Lee make more definitions to push factors. Lee proposed the impact factors which is intervening obstacles have on the migration process. ${ }^{6}$ Factors such as distance, physical and political barriers, also influenced the willing of original migration. Lee emphasized that the migration causing factors diversified as age, gender, and social class respond to people push-pull factors of migration. Furthermore, personal factors such as school education, family and friend connection that also the factors involved.

The rapid change in the globalization and science technology fast innovation caused no more clear employment prospects for graduates in most disciplines ${ }^{7}$ and apparently trying to pursuit well-to-do life, self - realization and being demanded are common for everyone. ${ }^{8}$

Globalization is primarily manifested in the possibility of educational mobility, and diversified learning and competition are the key to success in globalization. ${ }^{9}$ According Mazzarol research indicated that there were six 'pull' factors have been found to influence student selection of a host country. The first is pursuit better quality educationand knowledge, second is the outflow destination decision influenced by parents and relatives recommended. Third is expect lower tuition fees in the host education, forth is expect lower travel costs. Fifth is expect lower cost of living, and last is expect to have more job opportunities in the host. Obviously those pullfactors just as Ravenstein proposed that more practical and positive to graduates. ${ }^{10}$ Both push and pull factors are external forces which impact on graduates' behavior and choices, but much depends on the personal characteristics of the graduates. These characteristics include socio-economic status, academic ability, gender, age, motivation, and aspiration. . $^{11}$

Purposes Recently Taiwan graduates are looking at options other than the United States for study abroad opportunities. Some of the main reasons are economical. In fact, the number of Taiwan graduates in the United States had been declining gradually ever since it peaked in the mid-1990s.$^{12}$ Graduates from middle-class families are now more likely to consider possibilities other than the United States to reduce the cost. For the long-term low wages and soaring housing prices that causing most of Taiwan youths worried about the future of life. After China 31 incentives policies announced on February 2018 , the number of Taiwanese high school graduates applying to China universities has increased significantly.$^{13}$ This article hopes to design a scale to evaluate more high school graduates who eager to study abroad earlier at this critical moment.

\section{Research limitations}

Since Taiwan ruling authority kept hostile with China, most of recruited high school administrators hoped there were no negative description about home situations to avoid unnecessary trouble. So the push factors of this scale were being limited to represent and only could describe indirectly to evaluate graduates perspectives of source disadvantages. Therefore, the push factors must be modified and recoding to present what their truely implication

\footnotetext{
${ }^{4}$ E. G. Ravenstein(1885) The Laws of Migration Vol. 48(2) p.199

${ }^{5}$ Donald.J Bagne (1969) Principles of Demography New York : Johnson Wiley and Sons

${ }^{6}$ Everett S. Lee (1966) A Theory of Migration Demography Vol.3,(1) p.48

${ }^{7}$ Hong T. M. Bui, Hoa T. M. Nguyen, Doug Cole(2019) Innovate Higher Education to Enhance Graduate Employability: Rethinking the Possibility p.159

${ }^{8}$ Zhatkanbaeva (2012) The Impact of Globalization on "Brain Drain" in Developing Countries.p.1493

${ }^{9}$ Zhatkanbaeva (2012) The Impact of Globalization on "Brain Drain" in Developing Countries.p.1491

${ }^{10}$ Tim Mazzarol , Geoffrey Soutar (2002)" Push-Pull Factor Influencing International Student Destination Choice International Journal of Educational Management 16(2) pp.4-5

${ }^{11}$ Mei-Li, Mark Bray (2007) Cross-border flows of students for higher education: Push-pull factors and motivations of mainland Chinese students in Hong Kong and Macau p.794

${ }^{12}$ Carol Chen (2016/08/15) The Continuing Attraction for Taiwanese of Study Abroad Taiwan Business Topics

https://topics.amcham.com.tw > 2016/08 > continuing-attract

${ }^{13}$ Rachel Lin, Jennifer Huang, Su Meng-chuan and William Hetheri(2018) China targeting students using

Stipends Taipei Times Apr 03, 2018 . p. 3
} 


\section{Methods}

This validation scale included four-part questionnaires-- Part A, B and C were close-ended surveys , Part D was open-ended survey. Part A included four items to recognize graduates' background and BDR (Brain Drain Ratio) ( see Table 1). Part B comprised ten push factors items regarding graduates' perspectives of home disadvantages .

For meaning and clarity, we used a five-point Likert scale to classify intensions and recode their exact meanings ( $5=$ strongly agree, $4=$ somewhat agree, $3=$ neutral, $2=$ somewhat disagree, $1=$ strongly disagree). Scale scores were analyzed with descriptive statistics rankings (Table 2a), and examined by Exploratory Factor Analysis (EFA), as interrelated identifying items ${ }^{14}$ (Yong, Pearce 2013) (see Table 2b). Part C has ten pull factors items regarding graduates' perspectives of host advantages. Scale scores were also analyzed with descriptive statistics rankings (see Table 3a), examined by Exploratory Factor Analysis (EFA), as interrelated identifying items (see Table 3b). We used a five-point Likert scale to classify intensions and recoded them for their exact meaning. We created a variable (BDR) to represent the intensity of graduates' perspectives of brain drain. It consists of pull factors scores integrated $\mathrm{A}$ with push factors integrated $\mathrm{B}$, and $\mathrm{A} / \mathrm{B}$ represent $\mathrm{BDR}$. If the $\mathrm{BDR}$ is greater than one, means graduates more wish to brain drain than stay home and vice versa. We especially designed Part D open-ended items that could more valid and more reliable with unbiased reponse of brain drain preferences . .

\section{Participants}

A total of 230 high school graduates participated scale validation. By way of sending email to pursuit principals' helping to explain the scale contents and purposes, and class tutors recruit student volunteer to complete thisscale validation. For survey research intended to represent all schools, a response rate above $80 \%$ is expected ${ }^{15}$ This scale survey Effective responses are $92.7 \%$ (230 of 248).

\section{Instruments}

A 24-item close-ended scale and 2-item open-ended survey were developed based on literature review and consultation with three scholars and four high school counseling experts. We created a four domain subscales to validate high school graduates' perspectives of brain drain. Item A (1 to 4) is graduates' background andcharacteristics, item B (1 to 10) is brain drain push factors. Item C (1 to 10) is brain drain pull factors, item D (1 to 2) designed to confirm graduates' brain drain preferences . SPSS software (version 22.0) was provided for descriptive analysis, $\mathrm{T}$ test and one-way analysis of variance (ANOVA) were used to examine graduate' background and brain drain ratio (BDR) relationships. Exploratory factor analysis (EFA) were used to reduce the items of this scale to five sub-constructs, and to measure high school graduates' psychological traits such as attitudes, motivations, or abstract concept of intention. DeVellis(2003) proposed that rarely studies using less than 150 samples for EFA.16 We recruited 230 high school graduates from nationwide to represent their perspectives of brain drain . This article of Scale Content Validity provided from three professors and four high school experts, and Content Validity Index (CVI) divide into content suitability and text clarity . Content suitability scores from 0.86 to 0.97 , and text clarity scores from 0.83 to 1 that indicated the scale appropriateness and importance. ${ }^{16}$

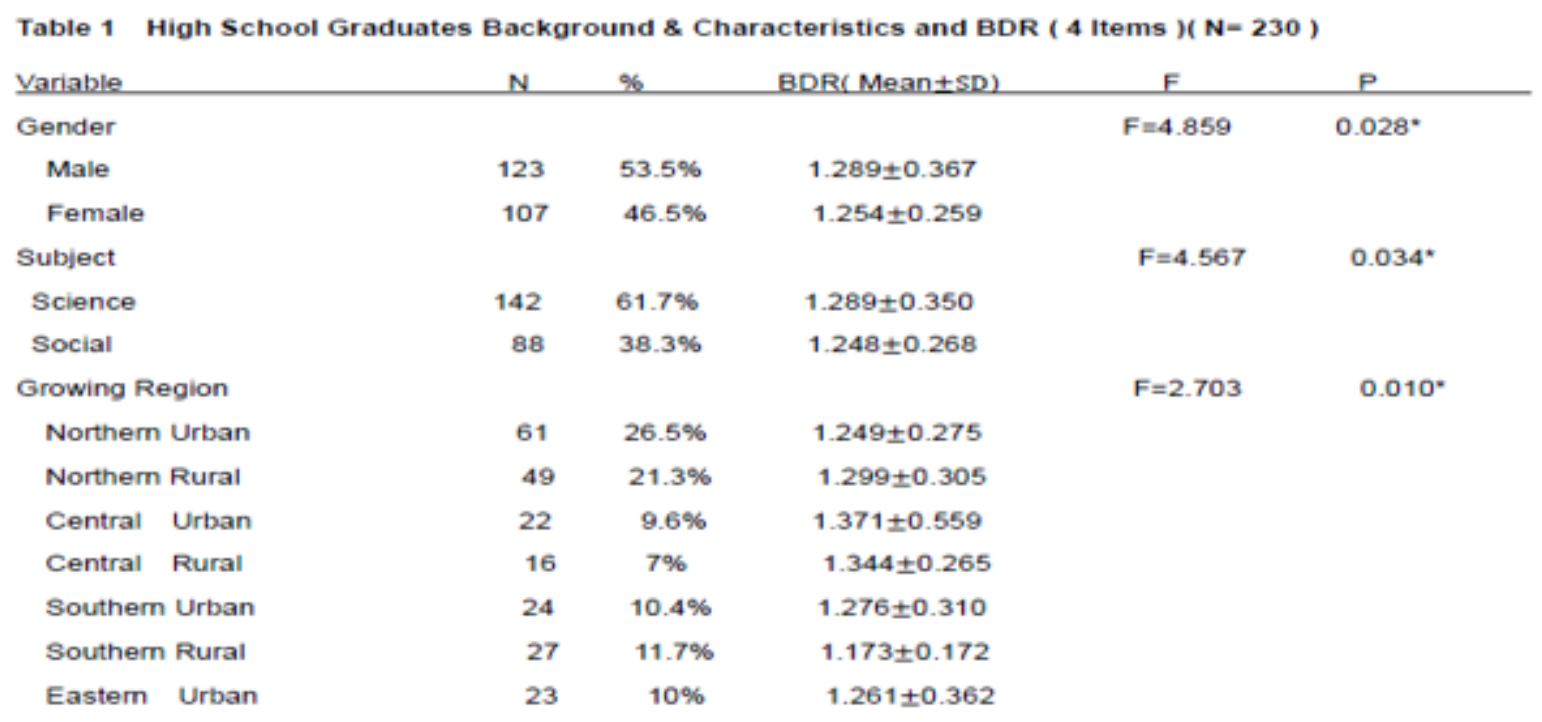

\footnotetext{
${ }^{14}$ Yong \& Pearce( 2013) A Beginner's Guide to Factor Analysis: Focusing on Exploratory Factor Analysis Tutorials in Quantitative Methods for Psychology Vol. 9(2) p. 83

15 Jack E. Fincham(2008) Response Rates and Responsiveness for Surveys, Standards, and the Journal $m$ J Pharm Educ Vol 72(2) p. 43

${ }^{16}$ Robert .F.Devellie(2003) Scale Development Theory and Applications (2nd ed.) p. 49
} 


\begin{tabular}{lccccc} 
Family Economic & & & & $F=0.662$ & 0.576 \\
Middle class & 27 & $11.7 \%$ & $1.263 \pm 0.353$ & & \\
Well-Off & 177 & $77 \%$ & $1.275 \pm 0.317$ & \\
Needy & 14 & $6.1 \%$ & $1.276 \pm 0.357$ & \\
Others & 12 & $5.2 \%$ & $1.257 \pm 0.308$ & \\
\hline
\end{tabular}

Table 2a Push factors analysis ( 10 Items )

1. Factor 1: Source Socioeconomic Advantages (Item 6.7.8.9)

2. Factor 2: Source Sociopolitical fare system (Item 1.2.3.4.5.10)

\begin{tabular}{llllll} 
Item & \multicolumn{1}{c}{ Content } & Mean & SD & Fac1 & Fac2 \\
6 & Domestic well health care system & 4.11 & 0.879 & 0.003 & 0.826 \\
8 & Social stable inviorment & 3.45 & 0.984 & 0.171 & $\mathbf{0 . 7 7 2}$ \\
7 & Stabilized domestic goods price & 3.13 & 0.869 & 0.403 & $\mathbf{0 . 6 6 7}$ \\
9 & Familiar learning \& employment & 3.66 & 0.983 & 0.302 & $\mathbf{0 . 6 1 2}$ \\
4 & Reasonable labor rights & 2.71 & 0.914 & $\mathbf{0 . 7 7 1}$ & 0.184 \\
2 & Optimistic domestic economic & 2.63 & 0.805 & $\mathbf{0 . 7 6 9}$ & 0.110 \\
5 & Domestic fair progression system & 2.66 & 0.995 & $\mathbf{0 . 7 2 0}$ & 0.093 \\
3 & Domestic stable politics & 2.65 & 0.975 & $\mathbf{0 . 6 3 5}$ & 0.262 \\
$10 \quad$ Domestic well innovation & 3.34 & 0.850 & $\mathbf{0 . 5 1 8}$ & 0.282 \\
1 & Domestic university excellent quality & 3.35 & 0.757 & $\mathbf{0 . 4 6 8}$ & 0.447 \\
Sum of squared loading (Eigenvalue) & & & 4.047 & 1.253 \\
Percentage of variance explained (\%) & & & 40.47 & 12.53 \\
Cumulative percentage of variance (\%) & & & 53.01 & 12.53 \\
Cronbach'a & & & 0.726 & 0.766
\end{tabular}

Note: $\mathrm{KMO}=0.85333 \quad \mathrm{Fac}=$ Factor

Iable 2a Summarv of item of Brain Drain Scale of push factors for hiah school araduates $(\mathrm{N}=230)$

\begin{tabular}{|c|c|c|c|c|c|c|c|c|c|}
\hline \multirow[b]{3}{*}{ Item } & \multirow[b]{3}{*}{ Mean } & \multicolumn{5}{|c|}{ Extreme group comparison } & \multirow{2}{*}{\multicolumn{3}{|c|}{$\begin{array}{l}\text { Homogeneity test } \\
\text { Item-total }\end{array}$}} \\
\hline & & & $\begin{array}{r}\text { Top } 2 \\
\text { gro }\end{array}$ & $\begin{array}{l}7 \% \\
\text { up }\end{array}$ & $\begin{array}{r}\text { Bottor } \\
\text { gro }\end{array}$ & $7 \%$ & & & \\
\hline & & $\mathrm{SD}$ & Mean & $\mathrm{SD}$ & Mean & $\mathrm{SD}$ & $T$ & $P \quad c$ & correlation \\
\hline Push factors & 3.90 & 0.53 & & & & & & & \\
\hline 1 Domestic university & 3.35 & 0.757 & 3.75 & 0.542 & 2.96 & 0.863 & 12.18 & 0.01 & 0.501 \\
\hline 2 Optimistic domestic economic & 2.63 & 0.805 & 3.22 & 0.570 & 2.01 & 0.606 & 12.89 & 0.00 & 0.500 \\
\hline 3 Domestic stable politics rights & 2.65 & 0.975 & 3.28 & 0.750 & 2.01 & 0.606 & 10.67 & 0.00 & 0.505 \\
\hline 4 Reasonable labor rights & 2.71 & 0.914 & 3.35 & 0.578 & 1.89 & 0.711 & 14.25 & 0.00 & 0.611 \\
\hline 5 Domestic fair progression system & 2.66 & 0.995 & 3.42 & 0.826 & 1.96 & 0.878 & 10.76 & 0.00 & 0.505 \\
\hline 6 Domestic well health care system & 4.11 & 0.879 & 4.74 & 0.441 & 3.37 & 0.837 & 13.13 & 0.00 & 0.425 \\
\hline 7 Stabilizied domestic goods price & 3.13 & 0.869 & 3.86 & 0.685 & 2.55 & 0.685 & 12.24 & 0.00 & 0.571 \\
\hline 8 Social stable enviorment & 3.45 & 0.984 & 4.30 & 0.601 & 2.65 & 0.688 & 16.29 & 0.00 & 0.480 \\
\hline 9 Familiar learning \& employment & 3.66 & 0.983 & 4.36 & 0.713 & 2.99 & 0.804 & 11.54 & 0.00 & 0.511 \\
\hline 10. Domestic well innovation & 3.34 & 0.850 & 3.81 & 0.601 & 2.88 & 0.877 & 783 & 0.00 & 0.393 \\
\hline
\end{tabular}


Table 3a Pull factors analysis ( 10 Items)

1. Factor 1: Source weak economic development (Item 6.7.8)

2. Factor 2: Host culture education Advantages (Item 3.4.5.9.10)

3. Factor 3 : family peers incentive (Item 1.2)

$\begin{array}{ll}\text { No } & \text { Content } \\ 1 & \text { Parents incentive influence } \\ 2 & \text { Teachers or peers encouragement } \\ 4 & \text { Yearning for foreign culture } \\ 3 & \text { Media network impact } \\ 5 & \text { Yearing for foreign talented pools } \\ 9 & \text { Yearing foreign flexible learning system } \\ 10 & \text { Yearing foreign diversified employment } \\ 7 & \text { Domestic lower wages } \\ 8 & \text { Domestic declining employment } \\ 6 & \text { Domestic economic stagnation } \\ \text { Sum of squared loading (Eigenvalue) } \\ \text { Percentage of variance explained (\%) } \\ \text { Cumulative percentage of variance (\%) } \\ \text { Cronbach'a }\end{array}$

$\begin{array}{lllll}\text { Mean } & \text { SD } & \text { Fac1 } & \text { Fac2 } & \text { Fac3 } \\ 3.53 & 0.945 & 0.113 & 0.093 & 0.881 \\ 3.53 & 0.838 & 0.112 & 0.341 & 0.778 \\ 4.07 & 0.780 & 0.054 & 0.833 & 0.168 \\ 3.63 & 0.838 & 0.086 & 0.786 & 0.197 \\ 4.11 & 0.821 & 0.361 & 0.781 & 0.067 \\ 4.08 & 0.845 & 0.517 & 0.552 & 0.167 \\ 3.75 & 0.864 & 0.418 & 0.513 & 0.227 \\ 4.14 & 0.797 & 0.860 & 0.193 & 0.097 \\ 3.85 & 0.887 & 0.836 & 0.073 & 0.047 \\ 3.99 & 0.851 & 0.830 & 0.218 & 0.124 \\ & & 4.490 & 1.482 & 1.001 \\ & & 44.89 & 14.82 & 10.01 \\ & & 44.89 & 59.71 & 69.73 \\ & & 0.627 & 0.814 & 0.702\end{array}$

Note: $\mathrm{KMO}=0.834 \quad \mathrm{Fac}=$ Factor

Iable $3 \mathrm{~b}$ Summarv of item of Brain Drain Scale of pull factors for high school araduates $(\mathrm{N}=230)$

\begin{tabular}{|c|c|c|c|c|c|c|c|c|c|}
\hline & \multirow[b]{3}{*}{ Mean } & \multirow[b]{3}{*}{$S D$} & \multicolumn{4}{|c|}{ Extreme group comparison } & \multirow{3}{*}{ r } & \multirow{2}{*}{\multicolumn{2}{|c|}{$\begin{array}{l}\text { Homogeneity test } \\
\text { Item-total }\end{array}$}} \\
\hline & & & \multicolumn{2}{|c|}{$\begin{array}{l}\text { Top } 27 \% \\
\text { group }\end{array}$} & \multicolumn{2}{|c|}{$\begin{array}{l}\text { Bottom } 27 \% \\
\text { group }\end{array}$} & & & \\
\hline Item & & & Mean & SD & Mean & $\mathrm{SD}$ & & $P \quad c$ & rrelation \\
\hline Pull factors & 3.899 & 0.533 & & & & & & & \\
\hline 1.Parents incentive influence & 3.53 & 0.945 & 4.36 & 0.569 & 2.74 & 0.612 & 18.42 & 0.15 & 0.333 \\
\hline 2. Teachers or peers encouragement & 3.53 & 0.838 & 4.24 & 0.603 & 2.95 & 0.565 & 14.81 & 0.00 & 0.484 \\
\hline 3.Media network impact & 3.63 & 0.838 & 4.36 & 0.626 & 3.05 & 0.575 & 13.21 & 0.00 & 0.499 \\
\hline 4. Yearning for foreign culture & 4.07 & 0.780 & 4.71 & 0.457 & 3.49 & 0.626 & 13.51 & 0.00 & 0.529 \\
\hline 5 Yearing for foreign talent pools & 4.11 & 0.821 & 4.83 & 0.379 & 3.37 & 0.635 & 16.95 & 0.00 & 0.683 \\
\hline 6 Domestic economic stagnation & 3.99 & 0.851 & 5.00 & 0.000 & 3.60 & 0.827 & 18.52 & 0.00 & 0.619 \\
\hline 7 Domestic lower wages & 4.14 & 0.797 & 5.00 & 0.000 & 3.84 & 0.792 & 15.98 & 0.00 & 0.636 \\
\hline 8 Domestic declining employment & 3.85 & 0.887 & 5.00 & 0.000 & 3.39 & 0.784 & 22.35 & 0.00 & 0.441 \\
\hline 9 Yearing foreign flexible learning system & 4.08 & 0.845 & 4.82 & 0.423 & 3.27 & 0.692 & 16.32 & 0.00 & 0.655 \\
\hline 10 Yearina foreian diversified emolovment & at $\quad 3.75$ & 0.864 & 4.50 & 0.683 & 3.04 & 0.538 & 14.51 & 0.00 & 0.579 \\
\hline
\end{tabular}


Table 4 Open-ended survey of the graduates' Brain Drain preferences ( 2 Items )( N=230)

\begin{tabular}{lcccc} 
Item & male No. $(\%)$ & female No. $\%)$ & science subject No. $(\%)$ & social subject No. $(\%)$ \\
Destination & & & & \\
U.S.A & $62(53.4 \%)$ & $36(37.1 \%)$ & $64(66 \%)$ & $33(34 \%)$ \\
China & $17(14.7 \%)$ & $17(17.5 \%)$ & $18(14 \%)$ & $16(19.3 \%)$ \\
Japan & $20(17.2 \%)$ & $11(11.3 \%)$ & $21(16.3 \%)$ & $10(12 \%)$ \\
U.K & $5(4.3 \%)$ & $16(16.5 \%)$ & $9(7 \%)$ & $12(14.5 \%)$ \\
Hong Kong & $4(3.4 \%)$ & $9(9.3 \%)$ & $9(7 \%)$ & $4(4.8 \%)$ \\
German & $6(5.2 \%)$ & $4(5.2 \%)$ & $4(3.1 \%)$ & $7(8.4 \%)$ \\
Total & 123 & 107 & 142 & 88 \\
Pursuit Goal & & & & $24(27.2 \%)$ \\
More development & $58(47.2 \%)$ & $30(28 \%)$ & $69(48.6 \%)$ & $28(31.7 \%)$ \\
Culture & $32(26 \%)$ & $35(32.7 \%)$ & $34(23.9 \%)$ & $13(14.8 \%)$ \\
Talent pools & $16(13 \%)$ & $16(15 \%)$ & $19(13.4 \%)$ & $15(17.2 \%)$ \\
Creative & $11(9 \%)$ & $16(15 \%)$ & $12(8.5 \%)$ & $6(6.9 \%)$ \\
Lower tuition & $3(2.4 \%)$ & $5(4.7 \%)$ & $2(1.4 \%)$ & $1(1.1 \%)$ \\
Familiar Enviorment & $2(1.6 \%)$ & $4(3.7 \%)$ & $5(3.5 \%)$ & $1(1.1 \%)$ \\
Lower admission criteria & $1(0.8 \%)$ & $1(0.9 \%)$ & $1(0.7 \%)$ & 88 \\
Total & $123 \% 7 \%)$ & 142 & \\
\hline
\end{tabular}

\section{Results}

\section{Part A High School Graduates Background \& characteristics and Brain Drain Ratio ( BDR )}

According Table 1 showed, We found that male BDR significant than female $(\mathrm{P}=0.028<0.05)$, means male 10 graduates more desiring to brain drain . Science subject graduates BDR significant than Non-science subject $(\mathrm{P}=0.034<0.05)$, means science subject graduates more desiring to brain drain . From different growing region BDR data that central urban and central rural graduates have higher BDR than others, and significant than other regions $(\mathrm{P}=0.010<0.05)$. We realized that test graduates from central region are elite high schools' graduates so that having higher BDR seems to be granted. Data also revealed that family economy seemed not bother graduates' outflow aspiration $(\mathrm{P}=0.576>0.05)$.

\section{Part B Push factors analysis}

As Table 2a showed, the validity using Exploratory factor analysis managed push factors extract to two factors. Most researchers tend to include items with higher loadings (at least $\mathbf{0 . 5}$ ) into the final scale (Schaufeli et al, 2002), ${ }^{17}$ Factor 1 represent Host Sociocultural Advantages, and each item factor loading from 0.468 to 0.771 . Factor 2 represent Home weak economy compare Host merits, and each item factor loading from $\mathbf{0 . 6 1 2}$ to 0.826 , indicated well extent to each item has discriminated between the high scorers and low scorers on the test. for exploratory factor analysis; KMO value is $\mathbf{0 . 8 5 3}$, indicated samples are adequate and significant $(\mathrm{p}<0.01)$ (Brace et al,2006) ${ }^{18}$; Cronbach's alpha value of factor 1 is $\mathbf{0 . 7 2 6}$ and Factor 2 is $\mathbf{0 . 7 6 6}$, which indicates a high level of internal consistency for the scale with these specific samples. Table $2 \mathrm{~b}$ showed push factors item- total correlation value of Factor 1 from $\mathbf{0 . 3 9 3}$ to $\mathbf{0 . 6 1 1}$, Factor 2 is from $\mathbf{0 . 4 2 5}$ to 0.571 , which indicated the item appropriate for the construct .

\section{Part C Pull factors analysis}

Table 3a showed the validity using Exploratory factor analysis managed pull factors extract to three factors . Factor 1 represents source disadvantages and loading values are from 0.830 to 0.860 .

\footnotetext{
${ }^{17}$ Rubio et al(2003)Objectifying content validity: Conducting a content validity study in social work research Social Work Research, Volume 27(2), pp.94-104

${ }^{18}$ Schaufeli et al (2002) The Measurement of Engagement and Burnout: A Two Sample Confirmatory Factor Analytic Approach Journal of Happiness Studies 3: pp71-92 
Factor 2 represents host advantages and loading values are from $\mathbf{0 . 5 1 3}$ to $\mathbf{0 . 8 3 3}$. Factor 3 represents family peers incentive and loading values are from $\mathbf{0 . 7 7 8}$ to $\mathbf{0 . 8 8 1}$. which indicated well extent to each item has discriminated between the high scores and low scores on the test. These three factors contributed a total $\mathbf{6 9 . 7 3 \%}$ of variance explained, and KMO value is 0.834 , also indicated samples are adequate and significant $(\mathrm{p}<0.01)$ (Brace et al,2006) .And Cronbach's alpha value of factor 1 is 0.627 and factor 2 is 0.814 , factor 3 is 0.702 . Which all indicated a well internal consistency for the scale with these specific samples . According to the literature, the corrected item-total correlation should be $>0.3$ (Groleger Sršen K, Vidmar G, Zupan A, 2015), As Table 3b showed pull factors item- total correlation value of Factor 1 from 0.441 to 0.636 , Factor 2 is from 0.499 to 0.683 , Factor 3 are 0.333 and 0.484 , which indicated the item appropriate for the construct .

\section{Part D Open-end survey of the graduates' first choice brain drain destination and pursuit goal}

From our scale data showed (Table 4) that U.S.A is still the first priority for Taiwan graduates' choice to study abroad . Male graduates choosed U.S.A for brain drain destination up to $\mathbf{5 3 . 4 \%}$, more than female(37.1\%), and science subject graduates $(\mathbf{6 6 \%})$ more than social subject(33\%). If we add the number of graduates who choose China and Hong Kong , then China apparently upgraded to be the second priority , male graduates have

$\mathbf{1 8 . 1} \%$ and female graduates have $\mathbf{2 6 . 8} \%$, and science subject graduates have $\mathbf{2 1 \%}$ that less than social subject (24.1 \%) . According Mainland Affairs Council datas, the number of graduates to China from 2011 to 2017 are 1433 to 2567 , and proportion from $4.7 \%$ to $7.9 \% .{ }^{19}$ Comparing with above datas that the nimber of graduates willing to study in China almost triple as before. We also found that the first prority for graduates' pursuit goal of brain drain is more development, male graduates have $\mathbf{4 7 . 2} \%$ much more than female ( $\mathbf{2 8} \%$ ), science subject graduates have $\mathbf{4 8 . 6} \%$ compare with non-science subject ( $\mathbf{2 7 . 2} \%$ ) . Better future seemed to be more attractive for Taiwan graduates than lower tuition and familiar enviorment .

\section{Conclusion}

In the spring of 2018, mainland China announced the China 31 incentives, which only for Taiwanese students to lower the admission criteria of Chinese elite universities. It did attract great attention and interests from high school students all over Taiwan. As a rising powerful dominant country, China has become a magnet for the world's talent pool . For having the chance to learn with world talent , the number of applicants for Chinese elite universities from Taiwan various places has increased significantly. Due to the long-term low wages and higher housing prices in Taiwan, most young people are simply unable to afford the general expenses of normal lifestyle. Lowering the admission standards had really encouraged many disqualified middle-level students dare to pursue the dreams that they never have. This study designed a scale of brain drain feasibility assessment for many Taiwan high school graduates who eager to study abroad. Helping more graduates who are interested in further study for better future development with this scale to confirm their intentions and the feasibility of studying abroad . We also expect to help teachers and counselors to acknowledge the actual demands of many potential students in a timely and appropriate manner based on this scale collecting datas. The data we collected from the scale found that the vast majority of high school graduates want to study abroad. More than half of the graduates studying abroad just for pursuing greater development. We realized that the second wave brain drain of Taiwan initiative .

\section{References}

Andrew Davis (1995) Criterion-referenced Assessment and the Development of Knowledge and Understanding Journal of Philosophy of Education Vol 29, Issue1. pp3-21

An Gie Yong, Sean Pearce (2013) A Beginner's Guide to Factor Analysis: Focusing on Exploratory Factor Analysis Tutorials in Quantitative Methods for Psychology Vol. 9(2) pp. 79-94.

Anna B. Costello and Jason W. Osborne (2005) Best Practices in Exploratory Factor Analysis: Four Recommendations for Getting the Most from Your Analysis Vol 10

Anthony Scott (1971) Review : The Brain Drain in Historical Perspective Minerva Vol 9, No 2

pp. 298-302

Aušra Kazlauskienè, Leonardas Rinkevičius(2006) Lithuanian "Brain Drain" Causes: Push and Pull Factors Engineering Economics No 1 (46) 13 Beavers,

A. S., Lounsbury,et .al (2013). Practical considerations for using exploratory factor analysis in educational research.PracticalAssessment, Research \&Evaluation,18(6),1-13. Available at : http://www.pareonline.net/pdf/v18n6.pdf

Bing-sheng Lee (2016) Taiwan Low Salary Causing Brain Drain The News Lens available at: https://international.thenewslens.com

\footnotetext{
${ }^{19}$ 2018/06/07 Taiwan Mainland Affairs Council deputy minister Chiu, Chui-Cheng : 5 years Taiwanese students go to China more than 2,000 people per year. www.mac.gov.tw
} 
Breinbauer, Andreas (2007) : Brain Drain - Brain Circulation or What Else Happens or Should Happen to the Brains Some Aspects of Qualified Person Mobility/Migration, FIW - Research Centre International Economics, Working Paper, No. 4 available at: http://hdl.handle.net/10419/121005

Carol Chen (2016) The Continuing Attraction for Taiwanese of Study Abroad Taiwan Business Topics Avail at : https://topics.amcham.com.tw > 2016/08 > continuing-attract

Chin-fen Chang (2018) Economic Inequality and low wages In Taiwan: Taiwan Insight. University of Nottingham online magazine of Taiwan Studies Programme.

C. Loring Brace, Noriko Seguchi, Conrad B. Quintyn, Sherry C. Fox, A. Russell Nelson, Sotiris K. Manolis, and Pan Qifeng (2006) "The questionable contribution of the Neolithic and the Bronzeage to European craniofacial form" Proceedings of National Academy Sciences vol 103 (1) 242-47, Available at : https://doi.org/10.1073/pnas.0509801102

De Vellis, R. F. (2003). Scale Development: Theory and Applications 2nd ed., Vol. 26

Devesh Kapur, John Mchale(2005), Give Us Your Best and Brightest: The Global Hunt for Talent and Its Impact on the Developing World Brookings institution press (7):87-109 .

Docquier, Frédéric; Rapoport, Hillel (2011), Globalization, brain drain and development, Working Paper, No. 18, Bar-Ilan University, Department of Economics.

Dodani, Sunita; LaPorte, Ronald E (2005).Brain Drain from Developing Countries: How can Brain Drain be Converted into Wisdom Gain? Journal of the Royal Society of Medicine. 98 (11): pp487-491. 14

Doris McGartland Rubio et al (2003) Objectifying content validity: Conducting a content validity study in social work research Social Work Research Vol. 27( 2) pp. 94-104

Douglas S. Massey, Joaquin Arango, Graeme Hugo, Ali Kouaouci, Adela Pellegrino and J. Edward Taylor (1993) Theories of International Migration: A Review and Appraisal Population and Development Review Vol. 19 (3) pp. 431-466.

E. G. Ravenstein(1885) The Laws of Migration Journal of the Statistical Society of London. Vol. 48. No.2. pp. 167-235 Blackwell Publishing for the Royal Statistical Society .available at: http://www.jstor.orglstable/2979181

Everett S. Lee (1966) A Theory of Migration Demography Vol. 3,(1) pp. 47-57.

Fazal Rizvi (2005) Rethinking "Brain Drain" in the Era of Globalization, Asia Pacific Journal of Education 25(2) pp 175-192

Fu-Lai Tony Yu (2012) Entrepreneurship and Taiwan's Economic Dynamics. Springer Science \& Business Media, pp. 59-61.

George Liao (2018) Taiwan’s average salary is NT\$50,000' doesn’t reflect reality: Minister of Labor Taiwan News, available at: https://www.taiwannews.com.tw

Gorsuch, R. L (1997) Exploratory factor analysis: Its role in item analysis Vol.68(3) pp.532-560

Groleger Sršen K, Vidmar G, Zupan A( 2015) Validity, internal consistency reliability and one-year stability of the Slovene translation of the Measure of Processes of Care Child Care Health Dev Volume 41(4) pp.569-80.

Guido Dorigo and Waldo Tobler (1983) Push-Pull Migration Laws Annals of the Association of American Geographers Vol. 73, No. 1 pp. 1-17 available at: https://www.jstor.org/stable/2569342

Hong-Chin Tsai(1988) A Study On The Migration Of Students From Taiwan To The United States : A Summary Report Journal of Population Studies No.12 pp.91-120

Hong T. M. Bui, Hoa T. M. Nguyen, Doug Cole(2019) Innovate Higher Education to Enhance Graduate Employability: Rethinking the Possibility pp.149-159 15

George Liao(2018) Taiwan's average salary is NT\$50,000' doesn't reflect reality: Minister of Labor Taiwan News available at: https://www.taiwannews.com.tw

James Baglin (2014) Improving Your Exploratory Factor Analysis for Ordinal Data: A Demonstration Using FACTOR Practical Assessment, Research \& Evaluation Vol 19

Jane Rickards (2018) What Gives with Taiwan's Low Wages? The News Lens available at: https://international.thenewslens.com/article/91779

Jason W. Osborne, Anna B. Costello \& J. Thomas Kellow (2008): Best Practices in Quantitative Methods: Best Practices in Exploratory Factor Analysis (chapter 6) pp.86-93.

Jessica Hagen-Zanker (2008) Why do people migrate? A review of the theoretical literature Maastrcht Graduate School of Governance Working Paper No. WP002

Judith Norton , Edward J. Barss translation (2018) China's 31 Measures East Asia Peace \& Security Initiative available at : https://www.eapasi.com

Juho Pesonen, Raija Komtopher Kronenberg, Mike Peters, (2011)Understanding the relationship between push and pull motivations in rural tourism, Tourism Review Vol. 66. pp.32 - 49.

Kainth, G.S. (2009)Push and Pull Factors of Migration: A Case of Brick Kiln Industry of Punjah State Asia-Pacific Journal of Social Sciences, Vol 1.pp. 82-116.

Kaz Miyagiwa(1991) Scale Economies in Education and the Brain Drain Problem . International Economic Review Vol. 32 (3) pp. 743-759. 
Kevin O'Neil (2003) Brain Drain and Gain: The Case of Taiwan, migration information source from the Migration Policy Institute. available at: Source@MigrationPolicy.org .

Khairul Azhar Mat Daud (2018) Validity and reliability of instrument to measure social media skills among small and medium entrepreneurs at Pengkalan Datu River International Journal of Development and Sustainability Vol 7 (3) pp.1026-1037 16

Leandre R. Fabrigar, Duane T. Wegener, Robert C. MacCallum, Erin J. Strahan (1999) Evaluating the use of exploratory factor analysis psychological research Vol 4(3) pp.272-299.

Mei-Li, Mark Bray (2007) Cross-border flows of students for higher education: Push-pull factors and motivations of mainland Chinese students in Hong Kong and Macau Higher Education Vol 53 .Issue 6. pp.791-818

Michel Beine, Fre'de'ric Docquier, Hillel Rapoport (2001) Brain drain and economic growth: theory and evidence, Journal of Development Economics Vol 64 pp. 275-289.

M. S. Bartlett (1951) A Further Note on Tests of Significance in Factor Analysis British Journal of Statistical Psychology Vol 4, Issue1 pp. 1-2

Parris Chang, Zhiduan Deng (1992), The Chinese brain drain and policy options Studies Comparative International Development Vol (27) Issue 1 pp. 44-60.

Petrin, Robert A, Schafft, Kai A, Mece, Judith L (2014)Educational Sorting and Residential Aspirations Among Rural High School Stuents: What Are the Contributions of Schools and Educators to Rural Brain Drain? American Educational Research Journal Vol.51(2), pp.294-326.

Polit, D. F., \& Beck, C. T. (2008). Is there gender bias in nursing research? Research in Nursing \& Health, Volume 31(5),pp. 417-427. Available at: http://dx.doi.org/10.1002/nur.20276

Rachel Lin, Jennifer Huang, Su Meng-chuan and William Hether(2018) China targeting students using stipends: source Taipei Times Apr 03, 2018 .p. 3 .Avail at : www.taipeitimes.com

Ralph Jennings(2018) Why Taiwan's Wages Are Low For A Developed Asian Economy Forbes . Avail at : https://www.forbes.com

Rosenthal, G. \& Rosenthal, J. (2011). Statistics and Data Interpretation for Social Work. Springer Publishing Company New York.

Schaufeli et al (2002) The Measurement of Engagement and Burnout: A Two Sample Confirmatory Factor Analytic Approach Journal of Happiness Studies 3: pp.71-92

Shirley L. Chang(1992) Causes of brain drain and solutions: The Taiwan experience, Studies Comparative International Development Vol(27), Issue 1, pp 27-43

Stacia E. Rodenbusch et al (2016)Early Engagement in Course-Based Research Increases Graduation Rates and Completion of Science, Engineering, and Mathematics DegreesCBE- Life Sciences Education Vol 15 (2)

Staffan Nilsson , Per-Erik Eilström (2012) "Employability and talent management: Challenges for HRD practices" European Journal of Training and Development Vol 36(1) . pp. 26-45 .

Sunita Dodani, Ronald E LaPorte (2005) Brain drain from developing countries: how can brain drain be converted into wisdom gain? Journal of the Royal Society of Medicine vol 98, pp.481-497.

Tain-Jy Chen, Ying-Hua Ku, Meng-Chun Liu (1995)" Direct investment in low-wage and high-wage countries: the case of Taiwan" Corporate Links and Foreign Direct Investment in Asia And the Pacific chap (12) pp.262274

Taiwan Mainland Affairs Council (2019) A Year After Mainland China Announced the 31 Taiwan-Related Measures, the Implementation Results are Overstated and the so-called "Favor Taiwan and Encourage Integration" intends to "Benefit China and Promote Unification" Press Release No. 028, available at https://www.mac.gov.tw

Tim Mazzarol , Geoffrey Soutar (2002)" Push-Pull Factor Influencing International Student Destination Choice International Journal of Educational Management Vol 16(2) pp.82-90

Ting-fang Hsiao (2017)"Farewell, Taiwan" Taiwan's Growing Talent Drain Common Wealth Magazine Vol 628

Victor Piché (2013) (translated by Catriona Dutreuilh) Contempoary Migration Theories As Reflected in Their Founding Texts I.N.E.D « Population » Vol 68. pp.141-164.

Viem Kwok and Hayne Leland (1982) An Economic Model of the Brain Drain the American Economic Review, Vol. 72(1) pp. 91-100.

Xiumei Zhang (2019) Migrant Population Services and Management Chinese Dream and Practice in ZhejiangSociety pp. 199-227

Yong \& Pearce( 2013) A Beginner's Guide to Factor Analysis: Focusing on Exploratory Factor Analysis Tutorials in Quantitative Methods for Psychology Vol 9(2) pp.79-94.

Zhatkanbaeva (2012) The Impact of Globalization on "Brain Drain" in Developing Countries. Procedia Social and Behavioral Sciences Vol 47 pp .1490-1494 